\title{
Perilaku Kerja Produktif dan Kontra Produktif: Sebuah Studi Meta-analisis
}

\author{
Ika Rahma Susilawati \\ ika.rahma.s@mail.ugm.ac.id
}

Fakultas Psikologi, Universitas Gadjah Mada, Yogyakarta, Indonesia

\begin{abstract}
Many studies has been conducted to investigate the relationship between two main domains in work performance. However, theoretical debates and discrepancies in empirical findings related to organizational citizenship behavior $(O C B)$ and counterproductive work behavior $(C W B)$ constructs have led researchers in industrial and organizational psychology to develop and reexamine similar studies in order to establish a more firmly connected view of $O C B$ and $C W B$ correlations and the existence of both constructs as a separated construct instead of a single continuum. This study aimed to investigate the strength of the relationship between $O C B$ and $C W B$ through a meta-analysis, namely bare bones meta-analysis. A total of 16 research articles and 32 research data were selected and used in this study. The results showed that corrected correlations between $O C B$ and $C W B$ from cross country samples and across professions was -0.3. The result leads to the conclusion that there is a significant negative correlation between $O C B$ and $C W B$, and this is consistent with previous metaanalysis studies.
\end{abstract}

Keywords: counterproductive work behavior; meta-analysis; organizational citizenship behavior

Penelitian yang menyelidiki hubungan antara dua domain utama dalam performa kerja telah banyak dilakukan, namun perdebatan teoritis dan perbedaan hasil temuan empiris terkait konstrak OCB dan CWB membuat sebagian peneliti dalam psikologi industri dan organisasi terus mengembangkan dan menguji kembali penelitian serupa untuk mengukuhkan pandangan yang lebih teguh terkait korelasi OCB dan CWB, serta keberadaan kedua konstrak tersebut sebagai dua konstrak yang berbeda dan terpisah. Penelitian ini bertujuan untuk menyelidiki kekuatan hubungan antara OCB dan CWB melalui teknik bare bones metaanalysis. Sebanyak 16 artikel penelitian dan 32 data penelitian telah terseleksi dan dinyatakan dapat digunakan dalam penelitian ini. Hasil analisis menunjukkan bahwa korelasi yang telah dikoreksi antara OCB dengan CWB dari sampel lintas negara, lintas profesi yaitu sebesar 0.3 . Hasil ini membawa pada kesimpulan adanya korelasi negatif yang signifikan antara OCB dengan CWB dan ini selaras dengan kajian-kajian studi meta-analisis yang pernah dilakukan pada sebelumnya.

Kata kunci: counterproductive work behavior; meta-analysis; organizational citizenship behavior

Received: January 5, 2018 Accepted: April 27, 2018

How to cite: Susilawati, I. R. (2018). Perilaku kerja produktif dan kontra produktif: Sebuah studi metaanalisis. MEDIAPSI, 4(1), 7-21. doi: https://doi.org/10.21776/ub.mps.2018.004.01.2

\section{Pendahuluan}

Performa kerja merupakan kajian yang sangat penting dalam psikologi industri dan organisasi. Performa kerja atau disebut juga sebagai kinerja atau work performance membentuk konteks psikologis, sosial dan juga organisasional dalam sebuah institusi kerja (Borman \& Motowidlo, 1997). Rotundo dan Sackett (2002) menyatakan ada tiga domain utama dalam performa kerja yaitu performa tugas, organizational citizenship behavior (OCB), dan counterproductive work behavior (CWB).

Cukup banyak periset yang tertarik 
menguji hubungan antara dua domain dalam performa kerja yaitu OCB dan CWB (Coyne, Gentile, Born, Ersoy, \& Vakola, 2013; Dalal, 2005; Dalal, Lam, Weiss, Welch, \& Hulin, 2009; Dunlop \& Lee, 2004; Miles, Borman, Spector, \& Fox, 2002; Sackett \& DeVore, 2001; Spector \& Fox, 2002; Spector \& Che, 2014). Beberapa temuan empiris mengenai hubungan OCB dan CWB belum memberikan gambaran yang selaras, di mana sebagian riset (Bennet \& Stamper, 2001; Puffer, 1987; Sackett, 2002; Sackett \& Devore, 2001; Viswesvaran, Schmidt, \& Ones, 1999) menunjukkan korelasi yang kuat, sedangkan beberapa riset lainnya menunjukkan korelasi yang lebih lemah antara kedua variabel (Dunlop \& Lee, 2004; Kelloway, Loughlin, Barling, \& Nault, 2002, Sackett, Berry, Wiemann, \& Laczo, 2006; O'Brien \& Allen, 2007). Beberapa penelitian menunjukkan korelasi positif (Ion, Mindu, \& Gorbanescu, 2017; Coyne, dkk, 2013 [hasil riset di Inggris dan Belanda]; Dalal, dkk, 2009; Fox, Spector, Goh, Bruursema, \& Kessler, 2012), sedangkan beberapa lainnya lebih banyak yang menunjukkan korelasi negatif (Dalal, 2005; Spector \& Fox, 2010; Coyne, dkk, 2013 [hasil riset pada orang Turki dan Yunani]). Studi meta-analisis yang dilakukan oleh Dalal (2005) menunjukkan rerata korelasi OCBCWB sebesar -0.32 dengan error pengukuran yang telah dikoreksi, dan $90 \%$ kredibilitas dengan rentang interval mulai dari -0.89 sampai 0.24 .

Sebagian periset menyebut bahwa konstrak OCB dan CWB merupakan konstrak kontinum tunggal di mana OCB disebut sebagai perilaku prososial sedangkan CWB disebut sebagai perilaku antisosial (dua kutub yang berlawanan dalam satu garis kontinum) (Bennet \& Stamper, 2001; Robinson \& Bennet, 1995). Namun kemudian beberapa periset mengemukakan bahwa OCB dan CWB tidaklah sama dan merupakan dua konstrak yang terpisah (Gruys \& Sackett, 2003). Kedua konstrak merupakan konstrak multidimensi di mana dalam subdimensi antara keduanya mungkin saja berkorelasi kuat sehingga terlihat sebagai sebuah konstrak yang sama (Dalal, 2005; Sackett, dkk, 2006; Spector, Bauer, \& Fox, 2010).

\section{Organizational Citizenship Behavior (OCB)}

Perilaku kerja produktif atau lebih dikenal dengan istilah Organizational Citizenship Behavior (OCB) didefinisikan sebagai perilaku karyawan yang secara sengaja dilakukan dan biasanya bersifat tidak bersyarat, bijaksana, tidak dikenali atau dihargai namun mampu meningkatkan fungsi organisasi (Organ, 1988; Schnake, 1991), namun kemudian dalam perkembangannya, OCB diakui dalam bentuk penilaian kinerja dalam organisasi (Organ, 1997). Organ dan koleganya (Dalal, 2005) menyebutkan ada dua dimensi dalam OCB yaitu dimensi interpersonal (disingkat OCB-I) contohnya secara sukarela membantu rekan kerja yang kesulitan dan dimensi organisasional (OCB-O) contohnya menyanjung dan membanggakan organisasi tempat kerja pada orang lain.

\section{Counterproductive Work Behavior (CWB)}

Perilaku kerja kontraproduktif atau lebih dikenal sebagai CWB atau disebut juga sebagai workplace deviance behavior atau disingkat WDB (Berry, Ones, \& Sackett, 2007; Hai \& Tziner, 2014) adalah bentuk perilaku disfungsional dan merugikan baik bagi individu maupun organisasi (Bennet \& Robinson, 2003). Perilaku ini merusak normanorma organisasi penting dan membahayakan organisasi dalam berbagai cara baik dari sisi pencapaian tujuan, aspek psikologis dan sosial karyawan, prosedur kerja, produktivitas 
maupun profitabilitas organisasi (Aube, Rousseau, Mama \& Morin, 2009; Dalal, 2005; Spector \& Fox, 2005; Spector, dkk, 2006). Menurut Robinson dan Bennet (1995), CWB juga memiliki dua dimensi yang berorientasi pada interpersonal (disebut CWB-I) contohnya bergosip tentang rekan kerja, dan berorientasi pada organisasional (disebut CWB-O) atau disebut juga sebagai workplace deviance contohnya mengambil cuti panjang melebihi batas haknya. Pekerja yang menunjukkan perilaku kontraproduktif cenderung lebih rentan mengalami stres dan memilih resign dari tempat kerjanya (O’Leary-Kelly, Griffin, \& Glew, 1996).

\section{Keterkaitan Organizational Citizenship Behavior (OCB) dengan Counterproductive Work Behavior (CWB)}

Hasil studi meta-analisis Dalal (2005) yang dilakukan di Amerika dengan responden dengan mayoritas mayoritas ras Kaukasia dan ada juga sebagian yang sampel warga Lebanon atau warga Arab, menemukan bahwa korelasi antara OCB dan CWB tidaklah kuat (-0.32) dan pola antiseden hubungan perilakuan antara keduanya berbeda. Dalal juga menambahkan prediksi analisis moderator yang menguatkan atau melemahkan korelasi negatif di antara OCB dan CWB, yaitu sumber rater atau penilai perilaku (supervisor, diri sendiri), butir antitesis (penggunaan butir ini pada setidaknya satu pengukuran perilaku), pilihan format respon (setuju-tidak setuju; ada sebagian yang menggunakan frekuensi perilaku), tingkat pendidikan rater (lulusan SMA atau perguruan tinggi).

Hasil empiris dan kerangka teoritis menunjukkan hubungan negatif di antara OCB dan CWB. Dalam beberapa studi ditemukan bahwa CWB merupakan bentuk ketidakpuasan yang menimbulkan emosi negatif, utamanya amarah, akibat dari ketidakadilan dan lingkungan yang penuh tekanan (Douglas \& Martinko, 2001; Fox, Spector, \& Miles, 2001) sedangkan OCB sebaliknya. Pekerja yang puas dan mempersepsikan dirinya mendapat perlakukan adil akan lebih terikat pada perilaku OCB dan terhindar dari perilaku CWB (Dalal, 2005). Pernyataan tersebut mendapat sanggahan dari beberapa peneliti lain yang mengatakan bahwa ada penekanan yang berlebihan pada perspektif pertukaran sosial atau keadilan sehingga mengabaikan faktor antiseden lain yang potensial memengaruhi korelasi keduanya (Bolino, 1999; Zellars \& Tepper, 2003). Spector dan Fox (2010) menyajikan lima situasi antiseden yang dapat menyebabkan OCB ataupun CWB, di antaranya yaitu kurang stimulasi dalam bekerja (yang kemudian memunculkan rasa bosan), hambatan organisasional (informasi yang tidak jelas, ketersediaan material/bahan kerja, sarana-prasarana, persiapan tugas), rendahnya performa rekan kerja, kurangnya reward atau penghargaan yang diperoleh (tidak sesuai dengan harapan), rasa bersalah atas kinerja sebelumnya.

Sebagian peneliti tergugah untuk melakukan pembuktian lebih lanjut atas hasil temuan Dalal (2005) melalui studi metaanalisisnya. Fox, dkk (2012) melakukan konfirmasi empiris melalui survei lapangan menggunakan alat ukur OCB yang secara khusus dikembangkan untuk menghilangkan butir antitesis yang saling tumpang tindih dan respon persetujuan (setuju-tidak setuju). Studi yang dilakukan di lima organisasi di Chicago dan Tampa menunjukkan bahwa OCB dan CWB berlawanan, namun keduanya bisa muncul dari individu yang sama dalam situasi yang berbeda. OCB muncul sebagai respon perilaku terhadap pengalaman positif di tempat kerja (diasosiasikan dengan emosi, persepsi, 
dan sikap positif), sedangkan CWB merupakan respon dari pengalaman negatif di tempat kerja. Perilaku merupakan sesuatu yang kompleks, berkaitan antara lingkungan dan individu yang bersifat dinamis sepanjang waktu.

Dari beberapa literatur yang telah dibahas, mayoritas merupakan hasil studi yang dilakukan di Amerika sehingga perlu diperluas dari sisi budaya dari negara lain apakah menghasilkan konklusi yang sama. Penelitian yang dilakukan oleh Coyne, dkk (2013) melakukan penelitian serupa di empat negara Eropa yaitu Inggris, Belanda, Yunani, dan Turki. Pendekatan lintas budaya digunakan dalam riset ini dan menghasilkan temuan yang mendukung riset Dalal (2005) bahwa OCB dan CWB merupakan konstruk yang multidimensi, bukan satu kontinum dengan dua kutub bipolar. Selain itu, bahwa alat ukur yang digunakan bersifat konvergen secara budaya, sehingga bisa digunakan lintas budaya/negara, termasuk di negara Asia seperti Mesir (Badawy \& El-Fekey, 2017), Korea (Jung \& Yoon, 2012), Pakistan (Bukhari \& Ali, 2009), Indonesia (Ariani, 2013), maupun negara lain seperti Rumania (Ion, dkk, 2017), Australia (Dunlop \& Lee, 2004).

Riset ini bertujuan untuk menelisik sejauh mana berbagai riset mengenai hubungan antara perilaku kerja produktif (diwakili oleh OCB) dan perilaku kerja kontraproduktif (diwakili CWB) dari berbagai negara, tidak hanya dari Amerika sebagaimana penelitian lain yang lebih banyak berfokus kesana. Riset ini menggunakan meta-analisis untuk menghitung estimasi kekuatan hubungan atau korelasi antara OCB dan CWB dari hasil berbagai riset yang sudah pernah dilakukan sebelumnya hingga hasil riset yang terkini.

\section{Metode}

\section{Pencarian literatur}

Artikel-artikel jurnal penelitian yang relevan ditelusuri melalui pangkalan data daring yang diakses melalui www.lib.ugm.ac.id yaitu J-Stor, Proquest, Elsevier, Emerald Insight, European Journal of Work \& Organizational Psychology, dan International Journal of Human Resources Management, dengan kata kunci pencarian yaitu "organizational citizenship behavior" dan "counterproductive work behavior" atau “deviance workplace behavior". Semua artikel yang relevan kemudian diulas dan dipertimbangkan menurut kriteria inklusi sebagai syarat untuk dapat digunakan sebagai data meta-analisis.

\section{Kriteria inklusi}

Kriteria seleksi artikel yang digunakan dalam riset ini adalah (1) studi primer yang membahas variabel OCB dan CWB dan berbagai istilah lain yang maknanya sama misal deviance workplace behavior; (2) dalam artikel tersebut mengandung informasi statistik yang diperlukan khususnya nilai rerata, standar deviasi, dan nilai $r$.

Dari 36 artikel yang diperoleh, terdapat 16 artikel yang memenuhi syarat dalam kriteria inklusi. Dari 16 artikel tersebut terdapat 32 data studi yang bisa digunakan sebagai data meta-analisis.

\section{Prosedur meta-analisis}

Teknik meta-analisis yang digunakan mengacu pada prosedur Hunter \& Schmidt (2004) dengan langkah sebagai berikut:

1. Transformasi nilai $\mathrm{F}$; mengubah persamaan aljabar dari nilai $\mathrm{F}$ menjadi nilai $\mathrm{t}, \mathrm{d}$, dan $\mathrm{r}$.

2. Bare bones meta-analysis untuk koreksi 
kesalahan sampling, dilakukan dengan:

- menghitung mean korelasi populasi

- menghitung variansi $r_{x y}$

- menghitung variansi kesalahan sampling

- dampak kesalahan sampling

\section{Hasil}

\section{Karakteristik sampel penelitian}

Adapun sampel penelitian yang dikaji dalam riset ini memiliki karakteristik sebagaimana yang tercantum daam Tabel 1 .

\section{Tahapan meta-analisis}

1. Transformasi nilai $F$, mengubah persamaan aljabar dari nilai $F$ menjadi $t, d$, dan $r$

Tahapan ini tidak dilakukan karena seleksi artikel penelitian sudah dilakukan secara selektif dengan mencari data dari penelitian-penelitian yang mengandung nilai korelasi $\left(r_{x y}\right)$.

\section{Bare bones meta-analysis}

- Menghitung mean korelasi populasi

Data penelitian dengan nilai korelasinya dapat dilihat selengkapnya pada Tabel 2 . Setelah nilai korelasi diperoleh, selanjutnya dilakukan koreksi kesalahan pengambilan sampel dengan bare bones meta- analysis. Jika korelasi populasi dianggap konstan antar hasil riset, maka estimasi terbaik untuk menghitung korelasi bukanlah rerata (mean) sederhana antar hasil riset namun rerata yang dibobot di mana korelasi dibobot dengan jumlah populasi (N) dalam riset tersebut (Hunter \& Schmidt, 2004). Maka estimasi terbaik untuk korelasi ini adalah dengan cara mengikuti rumus sebagai berikut:

$$
\bar{r}=\frac{\Sigma[N i . r i]}{\Sigma N i}
$$

Perhitungan koreksi kesalahan sampling dari data disajikan pada Tabel 3, di mana hasil estimasi rerata korelasi populasi setelah dikoreksi dengan jumlah sampel (̣) adalah sebesar -0.30 .

- Menghitung variansi $\mathrm{r}_{\mathrm{xy}}\left(\sigma^{2} \mathrm{r}\right)$

Variansi $r_{x y}$ atau $\sigma^{2} r$ dihitung dengan persamaan sebagai berikut:

$$
\sigma^{2} \mathrm{r}=\frac{\Sigma\left[N i\left(r_{i}-\bar{r}\right)^{2}\right]}{\Sigma N}
$$

Hasil perhitungan variansi $r_{x y}$ disajikan dalam Tabel 4, di mana dari perhitungan diketahui bahwa variansi $r_{x y}$ atau $\sigma^{2} r$ adalah 0.02425 , diperoleh dari:

$$
\begin{aligned}
& \sigma^{2} r=\frac{601.1345}{24789} \\
& \sigma^{2} r=0.02425
\end{aligned}
$$

- Variansi kesalahan sampling

Variansi $r_{x y}$ sebesar 0.02425 merupakan campuran dari dua hal yaitu variasi dalam korelasi populasi dan variasi dalam korelasi sampel yang dihasilkan oleh kesalahan sampling. Estimasi variansi dalam korelasi populasi dapat diperoleh hanya dengan mengkoreksi variansi $\sigma^{2} \mathrm{r}$ yang teramati untuk kesalahan sampling (Hunter \& Schmidt, 2004). Variansi kesalahan sampling dapat diestimasi dengan menggunakan rumus berikut:

$$
\sigma^{2} \mathrm{e}=\frac{\left((1-\bar{r})^{2}\right)^{2}}{(\bar{N}-1)}
$$

Maka variansi kesalahan sampling dari data meta-analisis ini adalah sebesar 0.00107037, dengan perhitungan seperti yang ditunjukkan pada persamaan di bawah ini:

$$
\begin{aligned}
\sigma^{2} \mathrm{e} & =\frac{\left(1-(-0.3)^{2}\right)^{2}}{(774.6563-1)} \\
\sigma^{2} \mathrm{e} & =\frac{0.8281}{773.6563} \\
\sigma^{2} \mathrm{e} & =0.00107037
\end{aligned}
$$


Tabel 1

Karakteristik Sampel Penelitian

\begin{tabular}{|c|c|c|c|c|c|}
\hline No. & Tahun & Peneliti & Studi ke- & Jumlah (N) & Karakteristik \\
\hline 1 & 2002 & $\begin{array}{l}\text { Miles, D. E., Borman, W. E., } \\
\text { Spector, P. E., \& Fox, S. }\end{array}$ & 1 & 203 & $\begin{array}{l}\text { Pekerja di berbagai perusahaan, } \\
\text { keuangan, hiburan, akademik }\end{array}$ \\
\hline 2 & 2004 & Dunlop, P. D., \& Lee, K. & 1.1 & 364 & $\begin{array}{l}\text { Pekerja di restoran fastfood Western } \\
\text { Australian }\end{array}$ \\
\hline 3 & 2004 & Dunlop, P. D., \& Lee, K. & 1.2 & 364 & $\begin{array}{l}\text { Pekerja di restoran fastfood Western } \\
\text { Australian }\end{array}$ \\
\hline 4 & 2004 & Dunlop, P. D., \& Lee, K. & 1.3 & 364 & $\begin{array}{l}\text { Pekerja di restoran fastfood Western } \\
\text { Australian }\end{array}$ \\
\hline 5 & 2005 & Dalal, R. S. & 1 & 16721 & $\begin{array}{l}\text { Pekerja dari berbagai bidang (staf } \\
\text { administrasi dan sekretariat, ahli IT, } \\
\text { edukator, pelajar yang bekerja, } \\
\text { supervisor, staf maintenance, } \\
\text { perawat, operator mesin, manajer }\end{array}$ \\
\hline 6 & 2006 & Sackett, P. R. & 1 & 900 & $\begin{array}{l}\text { Pekerja di unit nonakademik } \\
\text { universitas }\end{array}$ \\
\hline 7 & 2009 & Bukhari, Z. U., \& Ali, U. & 1 & 221 & $\begin{array}{l}\text { Pekerja sektor publik: perbankan dan } \\
\text { asuransi di Pakistan }\end{array}$ \\
\hline 8 & 2010 & $\begin{array}{l}\text { Spector, P. E., Bauer, J. A., \& } \\
\text { Fox, S. }\end{array}$ & 1.1 & 259 & $\begin{array}{l}\text { mahasiswa yang telah bekerja } \\
\text { (direkrut di universitas di } \\
\text { Southeastern USA) + supervisornya }\end{array}$ \\
\hline 9 & 2010 & $\begin{array}{l}\text { Spector, P. E., Bauer, J. A., \& } \\
\text { Fox, S. }\end{array}$ & 1.2 & 259 & $\begin{array}{l}\text { mahasiswa yang telah bekerja } \\
\text { (direkrut di universitas di } \\
\text { Southeastern USA) + supervisornya }\end{array}$ \\
\hline 10 & 2010 & $\begin{array}{l}\text { Spector, P. E., Bauer, J. A., \& } \\
\text { Fox, S. }\end{array}$ & 1.3 & 259 & $\begin{array}{l}\text { mahasiswa yang telah bekerja } \\
\text { (direkrut di universitas di } \\
\text { Southeastern USA) + supervisornya }\end{array}$ \\
\hline 11 & 2010 & $\begin{array}{l}\text { Spector, P. E., Bauer, J. A., \& } \\
\text { Fox, S. }\end{array}$ & 1.4 & 259 & $\begin{array}{l}\text { mahasiswa yang telah bekerja } \\
\text { (direkrut di universitas di } \\
\text { Southeastern USA) + supervisornya }\end{array}$ \\
\hline 12 & 2011 & $\begin{array}{l}\text { Fox, S., Spector, P. E., Goh, A., } \\
\text { Bruursema, K., \& Kessler, S. R. }\end{array}$ & 1.1 & 169 & $\begin{array}{l}\text { Pekerja di } 5 \text { organisasi di Chicago } \\
\text { dan Tampa }\end{array}$ \\
\hline 13 & 2011 & $\begin{array}{l}\text { Fox, S., Spector, P. E., Goh, A., } \\
\text { Bruursema, K., \& Kessler, S. R. }\end{array}$ & 1.2 & 169 & $\begin{array}{l}\text { Pekerja di } 5 \text { organisasi di Chicago } \\
\text { dan Tampa }\end{array}$ \\
\hline 14 & 2011 & $\begin{array}{l}\text { Fox, S., Spector, P. E., Goh, A., } \\
\text { Bruursema, K., \& Kessler, S. R. }\end{array}$ & 1.3 & 169 & $\begin{array}{l}\text { Pekerja di } 5 \text { organisasi di Chicago } \\
\text { dan Tampa }\end{array}$ \\
\hline 15 & 2012 & $\begin{array}{l}\text { Hafidz, S. W. M., Hoesni, S. } \\
\text { M., \& Fatimah, O. }\end{array}$ & 1 & 267 & $\begin{array}{l}\text { Mahasiswa psikologi yang memiliki } \\
\text { pengalaman bekerja part-time }\end{array}$ \\
\hline 16 & 2012 & Jung, H. S., \&Yoon, H. H. & 1 & 319 & Pekerja di hotel bintang 5 di Korea \\
\hline 17 & 2013 & Ariani, D. D. & 1 & 507 & $\begin{array}{l}\text { Pekerja di industri pelayanan jasa di } \\
\text { Yogyakarta }\end{array}$ \\
\hline 18 & 2013 & $\begin{array}{l}\text { Coyne, I., Gentile, D., Born, M., } \\
\text { Ersoy, N. C., \& Vakola, M. }\end{array}$ & 1.1 & 105 & $\begin{array}{l}\text { Pekerja di industri entertainment } \\
\text { untuk acara internasional di Inggris }\end{array}$ \\
\hline
\end{tabular}




\begin{tabular}{|c|c|c|c|c|c|}
\hline 19 & 2013 & $\begin{array}{l}\text { Coyne, I., Gentile, D., Born, M., } \\
\text { Ersoy, N. C., \& Vakola, M. }\end{array}$ & 1.2 & 105 & $\begin{array}{l}\text { Pekerja di industri entertainment } \\
\text { untuk acara internasional di Inggris }\end{array}$ \\
\hline 20 & 2013 & $\begin{array}{l}\text { Coyne, I., Gentile, D., Born, M., } \\
\text { Ersoy, N. C., \& Vakola, M. }\end{array}$ & 2.1 & 203 & $\begin{array}{l}\text { Pekerja di industri entertainment } \\
\text { untuk acara internasional di Belanda }\end{array}$ \\
\hline 21 & 2013 & $\begin{array}{l}\text { Coyne, I., Gentile, D., Born, M., } \\
\text { Ersoy, N. C., \& Vakola, M. }\end{array}$ & 2.2 & 203 & $\begin{array}{l}\text { Pekerja di industri entertainment } \\
\text { untuk acara internasional di Belanda }\end{array}$ \\
\hline 22 & 2013 & $\begin{array}{l}\text { Coyne, I., Gentile, D., Born, M., } \\
\text { Ersoy, N. C., \& Vakola, M. }\end{array}$ & 3.1 & 185 & $\begin{array}{l}\text { Pekerja di manufaktur produk kedelai } \\
\text { dan peternakan di Turki }\end{array}$ \\
\hline 23 & 2013 & $\begin{array}{l}\text { Coyne, I., Gentile, D., Born, M., } \\
\text { Ersoy, N. C., \& Vakola, M. }\end{array}$ & 3.2 & 185 & $\begin{array}{l}\text { Pekerja di manufaktur produk kedelai } \\
\text { dan peternakan di Turki }\end{array}$ \\
\hline 24 & 2013 & $\begin{array}{l}\text { Coyne, I., Gentile, D., Born, M., } \\
\text { Ersoy, N. C., \& Vakola, M. }\end{array}$ & 4.1 & 70 & $\begin{array}{l}\text { Pekerja di dua perusahaan farmasi di } \\
\text { Yunani }\end{array}$ \\
\hline 25 & 2013 & $\begin{array}{l}\text { Coyne, I., Gentile, D., Born, M., } \\
\text { Ersoy, N. C., \& Vakola, M. }\end{array}$ & 4.2 & 70 & $\begin{array}{l}\text { Pekerja di dua perusahaan farmasi di } \\
\text { Yunani }\end{array}$ \\
\hline 26 & 2014 & Spector, P. E., \& Che, X. X. & 1.1 & 146 & $\begin{array}{l}\text { Mahasiswa yang telah bekerja (teller, } \\
\text { customer service, farmasi, sopir bus, } \\
\text { sales, bartender) + supervisornya }\end{array}$ \\
\hline 27 & 2014 & Spector, P. E., \& Che, X. X. & 1.2 & 146 & $\begin{array}{l}\text { Mahasiswa yang telah bekerja (teller, } \\
\text { customer service, farmasi, sopir bus, } \\
\text { sales, bartender) + supervisornya }\end{array}$ \\
\hline 28 & 2014 & Spector, P. E., \& Che, X. X. & 1.3 & 146 & $\begin{array}{l}\text { Mahasiswa yang telah bekerja (teller, } \\
\text { customer service, farmasi, sopir bus, } \\
\text { sales, bartender) + supervisornya }\end{array}$ \\
\hline 29 & 2014 & Spector, P. E., \& Che, X. X. & 1.4 & 146 & $\begin{array}{l}\text { Mahasiswa yang telah bekerja (teller, } \\
\text { customer service, farmasi, sopir bus, } \\
\text { sales, bartender) + supervisornya }\end{array}$ \\
\hline 30 & 2017 & $\begin{array}{l}\text { Badawy, S. M., \& El-Fekey, S. } \\
\text { F. }\end{array}$ & 1 & 298 & $\begin{array}{l}\text { Pekerja di organisasi pemerintah dan } \\
\text { swasta di wilayah Kairo, Mesir }\end{array}$ \\
\hline 31 & 2017 & $\begin{array}{l}\text { Ion, A., Mindu., A., \& } \\
\text { Gorbanescu, A. }\end{array}$ & 1 & 170 & Pekerja di Rumania \\
\hline 32 & 2017 & $\begin{array}{l}\text { Thufail, M. S., Muneer, S., \& } \\
\text { Manzoor, M. }\end{array}$ & 1 & 170 & Frontline manager di bank \\
\hline
\end{tabular}

Tabel 2

Data Penelitian dengan Nilai F, t, d, dan r

\begin{tabular}{|c|c|c|c|c|c|c|}
\hline No. & Tahun & Peneliti & Jumlah (N) & $\mathbf{F}$ & d & $\mathbf{r}_{\mathbf{x y}}$ \\
\hline 1 & 2002 & $\begin{array}{l}\text { Miles, D. E., Borman, W. E., } \\
\text { Spector, P. E., \& Fox, S. }\end{array}$ & 203 & & & -0.11 \\
\hline 2 & 2004 & Dunlop, P. D., \& Lee, K. & 364 & & & -0.46 \\
\hline 3 & 2004 & Dunlop, P. D., \& Lee, K. & 364 & & & -0.32 \\
\hline 4 & 2004 & Dunlop, P. D., \& Lee, K. & 364 & & & -0.43 \\
\hline 5 & 2005 & Dalal, R. S. & 16721 & & & -0.32 \\
\hline 6 & 2006 & Sackett, P. R. & 900 & & & -0.39 \\
\hline 7 & 2009 & Bukhari, Z. U., \& Ali, U. & 221 & 267.679 & 16.36 & -0.742 \\
\hline
\end{tabular}




\begin{tabular}{|c|c|c|c|c|}
\hline 8 & 2010 & $\begin{array}{l}\text { Spector, P. E., Bauer, J. A., \& Fox, } \\
\text { S. }\end{array}$ & 259 & 0.21 \\
\hline 9 & 2010 & $\begin{array}{l}\text { Spector, P. E., Bauer, J. A., \& Fox, } \\
\text { S. }\end{array}$ & 259 & -0.37 \\
\hline 10 & 2010 & $\begin{array}{l}\text { Spector, P. E., Bauer, J. A., \& Fox, } \\
\text { S. }\end{array}$ & 259 & 0.01 \\
\hline 11 & 2010 & $\begin{array}{l}\text { Spector, P. E., Bauer, J. A., \& Fox, } \\
\text { S. }\end{array}$ & 259 & -0.46 \\
\hline 12 & 2011 & $\begin{array}{l}\text { Fox, S., Spector, P. E., Goh, A., } \\
\text { Bruursema, K., \& Kessler, S. R. }\end{array}$ & 169 & 0.16 \\
\hline 13 & 2011 & $\begin{array}{l}\text { Fox, S., Spector, P. E., Goh, A., } \\
\text { Bruursema, K., \& Kessler, S. R. }\end{array}$ & 169 & 0.11 \\
\hline 14 & 2011 & $\begin{array}{l}\text { Fox, S., Spector, P. E., Goh, A., } \\
\text { Bruursema, K., \& Kessler, S. R. }\end{array}$ & 169 & -0.44 \\
\hline 15 & 2012 & $\begin{array}{l}\text { Hafidz, S. W. M., Hoesni, S. M., \& } \\
\text { Fatimah, O. }\end{array}$ & 267 & -0.332 \\
\hline 16 & 2012 & Jung, H. S., \&Yoon, H. H. & 319 & -0.67 \\
\hline 17 & 2013 & Ariani, D. D. & 507 & -0.25 \\
\hline 18 & 2013 & $\begin{array}{l}\text { Coyne, I., Gentile, D., Born, M., } \\
\text { Ersoy, N. C., \& Vakola, M. }\end{array}$ & 105 & 0.15 \\
\hline 19 & 2013 & $\begin{array}{l}\text { Coyne, I., Gentile, D., Born, M., } \\
\text { Ersoy, N. C., \& Vakola, M. }\end{array}$ & 105 & 0.1 \\
\hline 20 & 2013 & $\begin{array}{l}\text { Coyne, I., Gentile, D., Born, M., } \\
\text { Ersoy, N. C., \& Vakola, M. }\end{array}$ & 203 & 0.2 \\
\hline 21 & 2013 & $\begin{array}{l}\text { Coyne, I., Gentile, D., Born, M., } \\
\text { Ersoy, N. C., \& Vakola, M. }\end{array}$ & 203 & 0.21 \\
\hline 22 & 2013 & $\begin{array}{l}\text { Coyne, I., Gentile, D., Born, M., } \\
\text { Ersoy, N. C., \& Vakola, M. }\end{array}$ & 185 & -0.06 \\
\hline 23 & 2013 & $\begin{array}{l}\text { Coyne, I., Gentile, D., Born, M., } \\
\text { Ersoy, N. C., \& Vakola, M. }\end{array}$ & 185 & -0.06 \\
\hline 24 & 2013 & $\begin{array}{l}\text { Coyne, I., Gentile, D., Born, M., } \\
\text { Ersoy, N. C., \& Vakola, M. }\end{array}$ & 70 & -0.08 \\
\hline 25 & 2013 & $\begin{array}{l}\text { Coyne, I., Gentile, D., Born, M., } \\
\text { Ersoy, N. C., \& Vakola, M. }\end{array}$ & 70 & -0.01 \\
\hline 26 & 2014 & Spector, P. E., \& Che, X. X. & 146 & -0.49 \\
\hline 27 & 2014 & Spector, P. E., \& Che, X. X. & 146 & -0.41 \\
\hline 28 & 2014 & Spector, P. E., \& Che, X. X. & 146 & -0.33 \\
\hline 29 & 2014 & Spector, P. E., \& Che, X. X. & 146 & -0.62 \\
\hline 30 & 2017 & Badawy, S. M., \& El-Fekey, S. F. & 298 & -0.378 \\
\hline 31 & 2017 & $\begin{array}{l}\text { Ion, A., Mindu., A., \& Gorbanescu, } \\
\text { A. }\end{array}$ & 170 & 0.23 \\
\hline 32 & 2017 & $\begin{array}{l}\text { Thufail, M. S., Muneer, S., \& } \\
\text { Manzoor, M. }\end{array}$ & 170 & -0.297 \\
\hline
\end{tabular}


Tabel 3

Koreksi Kesalahan Sampling

\begin{tabular}{|c|c|c|c|}
\hline No. Studi & $\mathbf{N}$ & $\mathbf{r}_{\mathbf{i}}$ & $\mathbf{N}_{\mathrm{i}} \mathbf{X} \mathbf{r}_{\mathbf{i}}$ \\
\hline 1 & 203 & -0.11 & -22.33 \\
\hline 2 & 364 & -0.46 & -167.44 \\
\hline 3 & 364 & -0.32 & -116.48 \\
\hline 4 & 364 & -0.43 & -156.52 \\
\hline 5 & 16721 & -0.32 & -5350.72 \\
\hline 6 & 900 & -0.39 & -351.00 \\
\hline 7 & 221 & -0.742 & -163.98 \\
\hline 8 & 259 & 0.21 & 54.39 \\
\hline 9 & 259 & -0.37 & -95.83 \\
\hline 10 & 259 & 0.01 & 2.59 \\
\hline 11 & 259 & -0.46 & -119.14 \\
\hline 12 & 169 & 0.16 & 27.04 \\
\hline 13 & 169 & 0.11 & 56.65 \\
\hline 14 & 169 & -0.44 & -226.60 \\
\hline 15 & 267 & -0.332 & -88.64 \\
\hline 16 & 319 & -0.67 & -213.73 \\
\hline 17 & 507 & -0.25 & -124.22 \\
\hline 18 & 105 & 0.15 & 15.75 \\
\hline 19 & 105 & 0.1 & 10.50 \\
\hline 20 & 203 & 0.2 & 40.60 \\
\hline 21 & 203 & 0.21 & 42.63 \\
\hline 22 & 185 & -0.06 & -11.10 \\
\hline 23 & 185 & -0.06 & -11.10 \\
\hline 24 & 70 & -0.08 & -5.60 \\
\hline 25 & 70 & -0.01 & -0.70 \\
\hline 26 & 146 & -0.49 & -68.60 \\
\hline 27 & 146 & -0.41 & -57.40 \\
\hline 28 & 146 & -0.33 & -46.20 \\
\hline
\end{tabular}

- Interval Kepercayaan

Jika korelasi populasi setelah dikoreksi dengan jumlah sampel $(\bar{r})$ memiliki distribusi normal, maka interval kepercayaan dapat dihitung dengan persamaan berikut:

$\bar{r} \pm 1.96 S D$

$\bar{r} \pm 1.96 x \sqrt{\sigma^{2} r}$

$\bar{r} \pm 1.96 x \sqrt{0.02425}$

$\bar{r} \pm 1.96 \times 0.1557$

$\bar{r} \pm 0.305$

$-0.3 \pm 0.305$

$-0.605<\bar{r}<0.005$

- Dampak kesalahan sampling

Dampak kesalahan sampling dapat diketahui dengan menggunakan rumus berikut:

$=\frac{\sigma^{2} e}{\sigma^{2} \rho} x 100 \%$

$=\frac{\sigma^{2} e}{\sigma^{2} \rho-\sigma^{2} e} \times 100 \%$

$=\frac{0.00107037}{0.02425-0.00107037} \times 100 \%$

$=\frac{0.00107037}{0.02317963} \times 100 \%$

$=4.62 \%$

Faktor kesalahan lain yang belum terspesifikasi sebesar $95.38 \%$.

\section{Diskusi}

Korelasi populasi yang sesungguhnya setelah dikoreksi oleh kesalahan sampling diestimasi sebesar -0.3. Variansi populasi sebesar 0.023. Interval kepercayaan dengan taraf $95 \%$ dalam batas penerimaan bergerak antara $-0.605<\bar{r}<0.005$. Dengan nilai $\bar{r}$ sebesar -0.3 artinya nilai korelasi berada di antara batas interval kepercayaan untuk diterima, sehingga dapat dikatakan bahwa hipotesis yang menyatakan ada korelasi antara OCB dan CWB dapat diterima. Nilai korelasi sebesar -0.3 tergolong dalam kategori agak lemah, di mana diperkirakan bahwa setiap kenaikan skor dalam variabel OCB maka akan 
Tabel 4

Variansi $r_{x y}$

\begin{tabular}{|c|c|c|c|c|c|}
\hline No. Studi & $\mathbf{N}$ & $\mathbf{r}_{\mathbf{i}}$ & $\left(\mathbf{r}_{\mathrm{i}}-\overline{\boldsymbol{r}}\right)$ & $\left(r_{i}-\bar{r}\right)^{2}$ & $\mathbf{N}\left(\mathbf{r}_{\mathrm{i}}-\overline{\boldsymbol{r}}\right)^{2}$ \\
\hline 1 & 203 & -0.11 & 0.19 & 0.0361 & 7.3283 \\
\hline 2 & 364 & -0.46 & -0.16 & 0.0256 & 9.3184 \\
\hline 3 & 364 & -0.32 & -0.02 & 0.0004 & 0.1456 \\
\hline 4 & 364 & -0.43 & -0.13 & 0.0169 & 6.1516 \\
\hline 5 & 16721 & -0.32 & -0.02 & 0.0004 & 6.6884 \\
\hline 6 & 900 & -0.39 & -0.09 & 0.0081 & 7.29 \\
\hline 7 & 221 & -0.742 & -0.44 & 0.195364 & 43.17544 \\
\hline 8 & 259 & 0.21 & 0.51 & 0.2601 & 67.3659 \\
\hline 9 & 259 & -0.37 & -0.07 & 0.0049 & 1.2691 \\
\hline 10 & 259 & 0.01 & 0.31 & 0.0961 & 24.8899 \\
\hline 11 & 259 & -0.46 & -0.16 & 0.0256 & 6.6304 \\
\hline 12 & 169 & 0.16 & 0.46 & 0.2116 & 35.7604 \\
\hline 13 & 169 & 0.11 & 0.41 & 0.1681 & 86.5715 \\
\hline 14 & 169 & -0.44 & -0.14 & 0.0196 & 10.094 \\
\hline 15 & 267 & -0.332 & -0.03 & 0.001024 & 0.273408 \\
\hline 16 & 319 & -0.67 & -0.37 & 0.1369 & 43.6711 \\
\hline 17 & 507 & -0.25 & 0.06 & 0.003025 & 1.533675 \\
\hline 18 & 105 & 0.15 & 0.45 & 0.2025 & 21.2625 \\
\hline 19 & 105 & 0.1 & 0.40 & 0.16 & 16.8 \\
\hline 20 & 203 & 0.2 & 0.50 & 0.25 & 50.75 \\
\hline 21 & 203 & 0.21 & 0.51 & 0.2601 & 52.8003 \\
\hline 22 & 185 & -0.06 & 0.24 & 0.0576 & 10.656 \\
\hline 23 & 185 & -0.06 & 0.24 & 0.0576 & 10.656 \\
\hline 24 & 70 & -0.08 & 0.22 & 0.0484 & 3.388 \\
\hline 25 & 70 & -0.01 & 0.29 & 0.0841 & 5.887 \\
\hline 26 & 146 & -0.49 & -0.19 & 0.0361 & 5.054 \\
\hline 27 & 146 & -0.41 & -0.11 & 0.0121 & 1.694 \\
\hline 28 & 146 & -0.33 & -0.03 & 0.0009 & 0.126 \\
\hline 29 & 146 & -0.62 & -0.32 & 0.1024 & 14.336 \\
\hline 30 & 298 & -0.378 & -0.08 & 0.006084 & 1.813032 \\
\hline 31 & 170 & 0.23 & 0.53 & 0.2809 & 47.753 \\
\hline 32 & 170 & -0.297 & 0.00 & $9 \mathrm{E}-06$ & 0.00153 \\
\hline
\end{tabular}




\begin{tabular}{cccc}
\hline Total & 24789 & & 601.1345 \\
\hline Rerata & 774.6563 & & 18.78545 \\
\hline & & $\mathrm{r}_{\mathrm{xy}}=601.1345 / 24789$ & 0.02425 \\
\hline
\end{tabular}

menunjukkan penurunan skor pada CWB. Semakin individu pekerja menunjukkan perilaku kerja produktif maka perilaku kerja kontraproduktifnya menurun. Demikian pula sebaliknya, semakin tinggi perilaku kerja kontraproduktifnya, maka semakin lemah perilaku kerja produktif individu tersebut.

Studi meta-analisis ini dilakukan dengan menggunakan data penelitian mulai tahun 2002 hingga 2017 dan menemukan hasil yang cukup konsisten dengan studi-studi sebelumnya. Riset ini mendukung studi metaanalisis yang sebelumnya telah dilakukan oleh Dalal (2005), di mana nilai korelasi yang telah dikoreksi bernilai 0.32. Berry, Ones, dan Sackett (2007) melalui studi meta-analisisnya menemukan bahwa OCB dan CWB yang berorientasi individu memiliki nilai korelasi yang lebih rendah (-0.15 sampai -0.24) daripada dengan CWB yang berorientasi pada organisasi (0.30 sampai 0.36). Hasil riset Kelloway, dkk (2002) menunjukkan korelasi sebesar -0.2 dalam menggunakan skala selfrating pada pekerja sektor publik berskala besar. Serupa dengan riset Bennet dan Robinson (2003) dalam penggunaan sampel atau partisipan, namun nilai korelasi dari risetnya bergerak pada rentang antara -0.28 sampai -0.35 .

Hasil riset ini bisa memberikan gambaran mengenai kekuatan korelasi antara OCB dengan CWB, namun anteseden maupun hubungan kausal yang menyebabkan kedua variabel tersebut belum terbahas dan masih sangat terbuka lebar untuk diselidiki lebih lanjut. Dalam riset ini juga memiliki beberapa limitasi. Pertama, studi meta-analisis dengan menggunakan teknik bare-bones yang hanya mengkoreksi kesalahan sampling memungkinkan terkandung bias didalamnya karena masih ada variansi dari perbedaan dalam reliabilitas antar studi, perbedaan dalam rentang maupun dikotomisasi respon serta perbedaan dalam validitas konstrak yang digunakan antar studi, sehingga variansi yang dihasilkan sangat mungkin menjadi estimasi yang agak jauh dari varians sesungguhnya (Hunter, \& Schmidt, 2004). Kedua, variasi sampel penelitian yang lebar di mana studi ini juga ditemukan pada lintas negara, memungkinkan adanya pengabaian terhadap faktor budaya atau konteks sosial yang mungkin berperan dalam pembentukan perilaku kerja produktif dan kontraproduktif (lihat Coyne, dkk, 2012). Penelitian ini tidak bisa mencantumkan variabel-variabel extraneous yang mungkin memiliki pengaruh besar terhadap pembentukan perilaku kerja tersebut. Ketiga, perdebatan mengenai apakah sebetulnya antara OCB dengan CWB merupakan konstrak tunggal dalam satu garis kontinum ataukah dua konstrak terpisah yang memiliki subdimensi yang saling berkorelasi, tidak dibahas dalam penelitian ini. Maka, diharapkan penelitian selanjutnya dapat berfokus pada limitasi yang ada pada penelitian ini.

\section{Daftar Pustaka}

Aube, C., Rousseau, V., Mama, C., \& Morin, E. (2009). Counterproductive behaviors 
and psychological well-being: The moderating effect of task interdependence. Journal of Business and Psychology, 24, 351-361. doi: https://doi.org/10.1007/s10869-009$\underline{9113-5}$

Badawy, S. M. \& El-Fekey, S. F. (2017). Does social comparison orientation moderate the organizational justice, in-role performance, citizenship and counterproductive behaviours relationships? International Journal of Business and Management, 12(12), 181193.

doi: https://doi.org/10.5539/ijbm.v12n12p18 1

Bennett, R. J., \& Robinson, S. L. (2000). Development of a measure of workplace deviance. Journal of Applied Psychology, 85(3), 349-360. doi: https://doi.org/10.1037/00219010.85.3.349

Bennett, R., \& Stamper, C. L. (2001). Corporate citizenship and deviancy: A study of discretionary work behavior. Dalam C. S. Galbraith (Ed.), Strategies and Organizations in Transition (hal. 265-284). Bingley, UK: Emerald Group Publishing Limited.

Berry, C. M., Ones, D. S., \& Sackett, P. R. (2007). Interpersonal deviance, organizational deviance, and their common correlates: A review and metaanalysis. Journal of Applied Psychology. 92(2), 410-424. doi: https://doi.org/10.1037/0021$\underline{9010.92 .2 .410}$

Bolino, M. C. (1999). Citizenship and impression management: Good soldiers or good actors? Academy of
Management Review, 24(1), 82-98. doi: https://doi.org/10.2307/259038

Borman , W. C., \& Motowidlo, S. J. (1993). Expanding the criterion domain to include elements of contextual performance. Dalam N. Schmitt, W. C. Borman, \& Associates (Eds.), Personnel Selection in Organizations (hal. 71-98). San Francisco: Wiley.

Bukhari, Z. U., \& Ali, U. (2009). Relationship between organizational citizenship behavior \& counterproductive work behavior in the geographical context of Pakistan. International Journal of Business and Management, 4(1), 85-92. doi:

https://doi.org/10.5539/ijbm.v4n1p85

Coyne, I., Gentile, D., Born, M., Ersoy, N. C., \& Vakola, M. (2013). The relationship between productive and counterproductive work behavior across four European countries. European Journal of Work and Organizational Psychology, 22(4), 377-389. doi: https://doi.org/10.1080/1359432X.2012. $\underline{673280}$

Dalal, R. S. (2005). A meta-analysis of the relationship between organizational citizenship behavior and counterproductive work behavior. Journal of Applied Psychology, 90(6), 1241-1255. doi: https://doi.org/10.1037/00219010.90.6.1241

Dalal, R. S., Lam, H., Weiss, H. M., Welch, E. R., \& Hulin, C. L. (2009). A withinperson approach to work behavior and performance: Concurrent and lagged citizenship-counterproductivity associations and dynamic relationships 
with affect and overall job performance. Academy of Management Journal, 52(5), 1051-1066. Diambil dari http://www.jstor.org/stable/40390331

Douglas, S. C., \& Martinko, M. J. (2001). Exploring the role of individual differences in the prediction of workplace aggression. Journal of Applied Psychology, 86(4), 547-559. doi: $\quad$ https://doi.org/10.1037/0021$\underline{9010.86 .4 .547}$

Dunlop, P. D., \& Lee, K. (2004). Workplace deviance, organizational citizenship behavior, and business unit performance: The bad apples do spoil the whole barrel. Journal of Organizational Behavior, 25(1), 6780. Diambil dari: https://www.jstor.org/stable/4093644

Fox, S., Spector, P. E., Goh, A., Bruursema, K., \& Kessler, S. R. (2012). The deviant citizen: Measuring potential positive relations between counterproductive work behaviour and organizational citizenship behaviour. Journal of Occupational and Organizational Psychology, 85(1), 199-220. doi: https://doi.org/10.1111/j.2044$\underline{8325.2011 .02032 . \mathrm{x}}$

Fox, S., Spector, P. E., \& Miles, D. (2001). Counterproductive work behavior (CWB) in response to job stressors and organizational justice: Some mediator and moderator tests for autonomy and emotions. Journal of Vocational Behavior, 59(3), 291-309. doi: https://doi.org/10.1006/jvbe.2001.1803

Gruys, M. L., \& Sackett, P. R. (2003). Investigating the dimensionality of counterproductive work behavior.
International Journal of Selection and Assessment, 11(1), 30-42. doi: https://doi.org/10.1111/14682389.00224

Hai, L. C., \& Tziner, A. (2014). Relationship between counterproductive work behavior, perceived justice and climate, occupational status, and leader-member exchange. Journal of Work and Organizational Psychology, 30(1), 1-12. https://doi.org/10.5093/tr2014a1

Hunter, J. E., \& Schmidt, F. L. (2004). Methods of Meta-analysis: Correcting Error and Biases in Research Findings $2^{\text {nd }}$ Edition. London: Sage Publications.

Ion, A., Mindu, A., \& Gorbanescu, A. (2017). Grit in the workplace: Hype or ripe? Personality and Individual Differences, 111, 163-168. doi: https://doi.org/10.1016/j.paid.2017.02.0 $\underline{12}$

Jung, H. S., \& Yoon, H. H. (2012). The effect of emotional intelligence on counterproductive work behaviors and organizational citizen behaviors among food and beverage employees in a deluxe hotel. International Journal of Hospitality Management, 31(2), 369378. doi: https://doi.org/10.1016/j.ijhm.2011.06.0 $\underline{08}$

Kelloway, E. K., Loughlin, C., Barling, J., \& Nault, A. (2002). Organizational citizenship and counterproductive behaviors: Separate but related constructs. International Journal of Selection and Assessment, 10(1-2), 143151. doi: https://doi.org/10.1111/14682389.00201

Miles, D. E., Borman, W. E., Spector, P. E., \& 
Fox, S. (2002). Building an integrative model of extra role work behaviors: A comparison of counterproductive work behavior with organizational citizenship behavior. International Journal of Selection and Assessment, 10(1-2), 5157. doi: https://doi.org/10.1111/14682389.00193

O'Brien, K. E., \& Allen, T. D. (2007). The relative importance of correlates of organizational citizenship behavior and counterproductive work behavior using multiple sources of data. Human Performance, 21(1), 62-88. doi: https://doi.org/10.1080/0895928070152 2189

O’Leary-Kelly, A. M., Griffin, R. W., \& Glew, D. J. (1996). Organization-motivated aggression: A research framework. Academy of Management Review, 21(1), 225-253. Diambil dari: http://www.jstor.org/stable/258635

Organ, D. W. (1988). Organizational Citizenship Behavior: The Good Soldier Syndrome. Lexington, MA: Lexington Books.

Organ, D. W. (1997). Organizational citizenship behavior: It's construct clean-up time. Human Performance, 10(2), 85-97. doi: https://doi.org/10.1207/s15327043hup1 $\underline{002 \_2}$

Puffer, S. M. (1987). Prosocial behavior, noncompliant behavior, and work performance among commission salespeople. Journal of Applied Psychology, 72(4), 615-621.

Robinson, S. L., \& Bennett, R. J. (1995) A typology of deviant workplace behaviors: A multidimensional scaling study. Academy of Management Journal, 38(2), 555-572. doi: https://doi.org/10.2307/256693

Rotundo, M., \& Sackett, P. R. (2002). The relative importance of task, citizenship, and counterproductive performance to global ratings of job performance: A policy-capturing approach. Journal of Applied Psychology, 87(1), 66-80. doi: https://doi.org/10.1037/00219010.87.1.66

Sackett, P. R. (2002). The structure of Counterproductive work behaviors: Dimensionality and relationships with facets of job performance. International Journal of Selection and Assessment, 10(1-2), 5-11. doi: https://doi.org/10.1111/14682389.00189

Sackett, P. R., Berry, C., Wiemann, S., \& Laczo, R. (2006). Citizenship and counterproductive behavior: Clarifying relations between the two domains. Human Performance, 19(4), 441-464. doi:

https://doi.org/10.1207/s15327043hup1 904_7

Sackett, P. R., \& DeVore, C. J. (2001). Counterproductive behaviors at work Dalam N. Anderson, D. S. Ones, H. K. Sinangil, \& C. Viswesvaran (Eds.), Handbook of Industrial, Work, \& Organizational Psychology Volume 1: Personnel Psychology (hal. 145-164). London, UK: Sage Publications.

Schnake, M. (1991). Organizational citizenship: A review, proposed model, and research agenda. Human Relations, 44(7), 735-759. doi: https://doi.org/10.1177/0018726791044 
$\underline{00706}$

Spector, P. E., Bauer, J. A., \& Fox, S. (2010).

Measurement artifacts in the assessment of counterproductive work behavior and organizational citizenship behavior: Do we know what we think we know? Journal of Applied Psychology, 95(4), 781-790.

doi: https://doi.org/10.1037/a0019477

Spector, P. E., \& Che, X. X. (2014). Reexamining citizenship: How the control of measurement artifacts observed relationship of organizational citizenship behavior and organizational variables. Human Performance, 27(2), 165-182. doi:

https://doi.org/10.1080/08959285.2014. $\underline{882928}$

Spector, P. E., \& Fox, S. (2005). A model of counterproductive work behavior. Dalam S. Fox \& P. E. Spector (Eds.), Counterproductive Workplace Behavior: Investigations of Actors and Targets (hal. 151-174). Washington, DC: APA.

Spector, P. E., \& Fox, S. (2002). An emotioncentered model of voluntary work behavior: Some parallels between counterproductive work behavior and organizational citizenship behavior. Human Resource Management Review, 12(2), 269-292. doi: https://doi.org/10.1016/S10534822(02)00049-9

Spector, P. E., \& Fox, S. (2010). Counterproductive work behavior and organizational citizenship behavior: Are they opposite forms of active behavior? Applied Psychology: An International Review, 59(1), 21-39. doi: https://doi.org/10.1111/j.1464$\underline{0597.2009 .00414 . \mathrm{X}}$

Spector, P. E., Fox, S., Penney, L. M., Bruursema, K., Goh, A., \& Kessler, S. (2006). The dimensionality of counterproductivity: Are all counterproductive behaviors created equal? Journal of Vocational Behavior, 68(3), 446-460. doi: https://doi.org/10.1016/j.jvb.2005.10.00 $\underline{5}$

Viswesvaran, C., Schmidt, F. L., \& Ones, D. S. (1999). The role of halo error in interdimensional ratings:The case of job performance ratings examined via metaanalysis. Dalam N. Anderson, D. S. Ones, H. K. Sinangil, \& C. Viswesvaran (Eds.), Handbook of Industrial, Work, \& Organizational Psychology Volume 1: Personnel Psychology (hal. 145-164). London, UK: Sage Publications.

Zellars, K. L., \& Tepper, B. J. (2003). Beyond social exchange: New directions for organizational citizenship behavior theory and research. Dalam M. R. Buckley, J. R. B., Halbesleben, A. R. Wheeler (Eds.), Research in Personnel and Human Resources Management Volume 22 (hal. 395-424). Bingley, UK: Emerald Group Publishing Limited. 